\title{
How Are Foreign Firms Valued in U.S. Markets? Evidence from Firm and Country Characteristics
}

\author{
Xiaoxiao Song ${ }^{1}$ \\ ${ }^{1}$ School of Business, Southern Illinois University Edwardsville, USA \\ Correspondence: Xiaoxiao Song, School of Business, Southern Illinois University Edwardsville, USA. E-mail: \\ xsong@siue.edu
}

Received: July 18, 2019

Accepted: October 8, 2019

Online Published: October 12, 2019

doi:10.5430/afr.v8n4p101

URL: https://doi.org/10.5430/afr.v8n4p101

\begin{abstract}
This paper investigates the determinants of foreign firms' value in U.S. markets by examining both firm and country characteristics. Prior studies have agreed on foreign firms' value premium when they cross-list stocks in U.S. exchanges. However, little research has pursued evidence regarding how these foreign firms are valued after the cross-listing. I attempt to answer this question by comparing the determinants of firm value for both foreign cross-listing firms and U.S. domestic firms. The results from regression models show that, although foreign firms share similar firm-level determinants with U.S. firms (firm size, firm leverage, and firm growth), they are on average undervalued by U.S. investors. Furthermore, the home countries' characteristics, such as the rule of law, play an important role in foreign firms' market value. In fact, the undervaluation is only observed in foreign firms from the weak rule of law countries, but not from strong rule of law countries. Overall, foreign firms' market value is determined by both firm-level and country-level characteristics after they cross-list in the U.S. markets.
\end{abstract}

Keywords: U.S. markets, cross-listing, firm value, home country

\section{Introduction}

The accelerating pace of globalization in financial markets has facilitated cross-border trading and cross-listing in recent decades. In the 1980s, only around 200 foreign firms traded their stocks on AMEX, NASDAQ, and NYSE. However, in the last ten years, this number has soared to more than 800 , which is almost four times more than 30 observed years ago. (Note 1)

Prior research has provided various reasons for firms to adopt a cross-listing strategy, such as improving liquidity, overcoming market segmentation, increasing visibility, and enhancing corporate governance (Mittoo, 1992; Karolyi, 1998; Coffee, 2002; Karolyi \& Stulz, 2003; Ferris \& Liao, 2018). Doidge, Karolyi, and Stulz (2004) notice that foreign firms' market value increased as high as 37\% when they listed stocks on the U.S. major markets. However, little research has been conducted to examine how these foreign firms are valued after the cross-listing. If foreign firms follow the same regulations as domestic firms, they might have the same value as their domestic counterparts. On the other hand, prior studies have suggested that U.S. investors show the tendency to over-invest in local stocks and under-invest in global securities, a phenomenon referred to as "home bias" (Lewis, 1999; Karolyi \& Stulz 2003). If this is the case, then foreign firms might be undervalued due to the lower demand from U.S. investors.

To address this question, I first examine firm value determinants for foreign cross-listing firms and U.S. domestic firms separately. Regression results suggest that both types of firms have similar firm-level determinants. In general, smaller firms, less leveraged firms, and rapidly growing firms usually have a higher market value that is measured by the Tobin's q ratio. Next, I investigate whether the two types of firms are valued differently from the country level. A dummy variable "Foreign" is created based on the country of a firm's headquarters. The negative coefficient on this variable indicts that, on average, foreign firms' Tobin's q ratio is 5.6\% lower than the ratio of U.S. domestic firms, after controlling for firm-level factors.

After observing the similarities and differences between foreign and domestic firms, I follow prior studies (Srinivasan, Wahid \& Yu, 2015; Wilford, 2016; El-Gazzar \& Finn, 2017) and perform cross-sectional analyses to examine whether foreign firms' value depends on the characteristics of their home countries. Using the Rule of Law (ROL) index (Note 2) as the proxy for countries' legal systems, I find that foreign firms' market value is positively correlated with their home countries' ROL. In fact, the undervaluation between cross-listing firms and U.S. firms 
disappears when foreign firms are from countries with strong ROL. All findings are robust with different sample observations and ROL measures.

My study contributes to international accounting and global finance in two ways. Firstly, although numerous studies have reviewed the motivations of firms' cross-listing strategy, most of them focus on comparing cross-listers with non-cross-listers. There is little evidence regarding how these foreign firms are valued after listing shares in the U.S. My study shows that, despite the value premium for foreign cross-listers, they experience an undervaluation relative to their domestic counterparts. Foreign firms must take this undervaluation into consideration when they make cross-listing decisions.

Secondly, this paper examines foreign firms' value in terms of both firm characteristics and country characteristics. Prior literature has investigated firm-level determinants for U.S. domestic firms and generally agreed that firms with smaller size, lower leverage ratio, and faster-growing trends are usually valued higher (Daines, 2001; Maury \& Pajuste, 2005; Faleye, 2007; Brick \& Chidambaran, 2010; Ammann, Oesch \& Schmid, 2011). My study not only extends these determinants to foreign firms but also demonstrates the importance of home countries' characteristics on foreign firms' market value in the U.S. Although on average foreign firms are undervalued by U.S. investors, a strong legal system in foreign firms' home countries can effectively offset the negative bias. These findings can be useful for potential investors, stock analysts, and policy setters.

\section{Literature Review and Hypotheses Development}

\subsection{Literature Review}

Prior research has provided various motivations for foreign firms' cross-listing strategy. Firstly, foreign firms can improve their liquidity when they cross-list their shares to the U.S. with more liquid exchange centers. Smith and Sofianos (1997) observe increased trading volume, stock turnover, and share price for 128 NYSE-listed foreign firms. Another incentive for cross-listing is to overcome global trading barriers and market segments by raising funds from more exchanges and enlarged investor bases. Foerster and Karolyi (1998) state that "when such a company interlists in another market that is integrated globally, the investment barriers are finessed, the extra risk premium dissipates, and its cost of capital declines" (page 395).

The third reason for foreign firms to cross-list in U.S. markets is to bond themselves to a better regulatory environment. By accessing the U.S. strict legal system, foreign firms can reduce insiders' expropriations and better protect minority investors. This benefit is more valuable to foreign firms when they come from countries with weak legal systems or enforcement powers. The bonding theory is supported by empirical studies that confirm the U.S. cross-listing is associated with decreased cost of capital (Leuz, 2003), enhanced share price and market value (Doidge et al., 2004; Hail \& Leuz, 2009), and improved corporate governance (Lang, Raedy \& Wilson, 2006; Fresard \& Salva, 2010).

In particular, Doidge et al. (2004) directly test the change in foreign firms' market value (proxied by Tobin's q ratio) after they cross-listed stocks in the U.S. The results show that cross-listers in U.S. major markets experience a 37\% increase in their Tobin's q ratio relative to the non-cross-listers from the same country. The value premium is attributed to the reduced expropriation from controlling shareholders and to the improved corporate governance. Compared with non-cross-listers, U.S. cross-listers have more growth opportunities, which are positively priced and valued by market participants.

\subsection{Hypotheses Development}

Prior studies that examine the determinants of U.S. domestic firms' value have agreed on certain common firm-level characteristics, such as size, leverage, and growth. Since foreign cross-listing firms follow the same rules and regulations as domestic firms, it is possible that these determinants also apply to foreign firms. For example, like domestic firms, cross-listing firms must report their annual financial statements to the SEC and are subject to the same scrutiny. Foreign firms also need to follow the SOX Act and protect minority investors. Due to the similarities between the two types of firms, some studies (Sun, Cahan \& Emanuel, 2011; Kaya \& Pillhofer, 2013) treat foreign cross-listing firms as surrogates for U.S. firms. Therefore, the first hypothesis is stated as follows:

Hypothesis 1. U.S. foreign cross-listing firms and U.S. domestic firms have the same firm-level value determinants in U.S. markets.

Despite the globalization of capital markets, U.S. investors still tend to over-invest in domestic stocks and under-invest in foreign securities, a demonstration noted as "home bias." Results from French and Poterba (1991) illustrate that, out of U.S. investors' equity portfolios, almost $94 \%$ is allocated to domestic securities, which 
contradicts the rational investment strategies with international diversification benefits. Strong and Xu (2003) investigate the possible reasons for the "home bias" by reviewing the Merrill Lynch 1998 Fund Manager Survey. They report that U.S. mutual fund managers have a significant relative optimism towards their domestic stocks.

Due to the home bias from investors and other market participants, foreign firms usually incur higher costs when they enter the U.S. capital market. Bell, Filatotchev, and Rasheed (2012) mention that foreign firms "could potentially pay higher underwriting fees, higher professional fees, or higher initial listing fees than local firms... resulting in lower trading volume and therefore reduced liquidity" (page 111). Supporting this statement, Smith, Gleason, Wiggenhorn, and Kannan (2018) provide evidence that foreign cross-listing firms are charged with higher auditing fees, compared with the auditing fees for U.S. domestic firms.

The home bias phenomenon indicates that U.S. investors usually have a higher demand for domestic equities and a lower preference to foreign securities. Therefore, foreign firms might be valued lower with discounted demand. The second hypothesis is stated as follows:

Hypothesis 2. U.S. foreign cross-listing firms are undervalued compared to U.S. domestic firms in U.S. markets.

Lastly, I test whether foreign firms' value varies with legal systems in their home countries. Prior studies demonstrate that foreign firms' behavior is strongly influenced by their home countries' characteristics. Results from Bonetti and Bozzolan (2015) suggest that foreign firms who comply with SOX302 have a greater analyst following and an improved information environment. The observed positive outcomes depend on the legal systems in these foreign firms' home countries. Similarly, Srinivasan et al. (2015) confirm the importance of home countries' characteristics by showing that foreign firms from weak legal systems have more opportunistic reporting incentives. Wilford (2016) also concludes that foreign firms' internal control weaknesses are correlated with the legal systems in their home countries.

Given the heterogeneous legal systems in foreign firms' home countries, I predict that foreign firms' value is associated with their home countries' characteristics, such as the legal systems. The last hypothesis is stated as follows:

Hypothesis 3. U.S. foreign cross-listing firms' value in U.S. markets is associated with their home countries' legal systems.

\section{Methodology, Data, and Sample}

To test Hypothesis 1, I identify the widely used determinants of firm value and test these variables separately for foreign cross-listing firms and U.S. domestic firms. Following prior studies (Lindenberg \& Ross, 1981; Chung \& Pruitt, 1994; Callahana, Millar \& Schulman, 2003; Oxelheim \& Randøy, 2003), I measure firms' market value with the Tobin's q ratio.

$$
\text { Tobin's } q_{i t}=\alpha_{0}+\alpha_{1} \text { Size }_{i t}+\alpha_{2} L E V_{i t}+\alpha_{3} \text { Grow }_{i t}+\text { Year Dummies }+\varepsilon_{i t}
$$

Where:

Tobin's $q_{i t}=\left(\right.$ Common equity's market value $\left(C S H O * P R C C_{-} F\right)+$ preferred equity's book value $(P S T K)+$ debt $(D L T T+D L C)) /$ total assets $(A T)$.

Size $_{i t}=$ Firm size, measured as the natural logarithm of firm $i$ 's total assets (AT).

$L E V_{i t}=$ Firm leverage ratio, measured as firm $i$ 's debt $(D L T T+D L C)$ over total assets $(A T)$.

Grow $_{i t}=$ Firm growth, measured as firm i's percentage change of sales (SALE) from year $t-1$ to year $t$.

These firm-level determinates are commonly used in other studies (Daines, 2001; Maury \& Pajuste, 2005; Faleye, 2007; Brick \& Chidambaran, 2010; Ammann et al., 2011). $\alpha_{1}$ is predicted to be negative, since smaller firms are usually at the growth stage with more value-increasing opportunities relative to larger firms. A high debt level may hinder a firm's value for three reasons. Firstly, firms with high debt face a higher likelihood of bankruptcy and financial distress. Secondly, the free cash flow might be used to first pay debtholders instead of seizing the growing chances. Thirdly, high leveraged firms have more constraints and uncertainties imposed by debt contracts and covenants. Therefore, $\alpha_{2}$ is predicted to be negative. Growth is measured as a firm's percentage change of sales from the previous year to the current year, and $\alpha_{3}$ is expected to be positive. Investors prefer rapidly growing firms with high return potential. I also include year dummies in the model to control for any unobservable factors over time.

To test Hypothesis 2, I create a dummy variable "Foreign" based on the country of a firm's headquarters.

$$
\text { Tobin's } q_{i t}=\alpha_{0}+\alpha_{1} \text { Foreign }_{i t}+\alpha_{2} \text { Size }_{i t}+\alpha_{3} L E V_{i t}+\alpha_{4} \text { Grow }_{i t}+\text { Year Dummies }+\varepsilon_{i t}
$$


Foreign $_{i t}=$ A dummy variable that equals 1 for firm $i$ when it is headquartered outside of the U.S. and 0 otherwise.

To test Hypothesis 3, I create a dummy variable "Strong" based on the score of home countries' Rule of Law (ROL) index.

$$
\text { Tobin's } q_{i t}=\alpha_{0}+\alpha_{1} \text { Strong }_{i t}+\alpha_{2} \text { Size }_{i t}+\alpha_{3} L E V_{i t}+\alpha_{4} \text { Grow }_{i t}+\text { Year Dummies }+\varepsilon_{i t}
$$

Strong $_{i t}=$ A dummy variable that equals 1 if the ROL index in foreign firm $i$ 's home country is above the sample's median and 0 otherwise.

Data for firm-level variables (Tobin's q, Size, LEV, and Grow) and firms' headquarters is obtained from Compustat. The World Bank website (Note 3) provides the ROL index. The sample contains all firms traded on the three major stock exchanges (AMEX, NASDAQ, and NYSE) from year 2000 to year 2017. Firms in financial industries and regulated industries are excluded because they follow different rules and are valued differently. There are 57,586 firm-year observations in the full sample.

Table 1 illustrates the sample distribution by country (Panel A) and by year (Panel B) for the full sample. Foreign firms in total represent $15.9 \%$ of all observations, and Canada is the leading foreign country $(3.52 \%)$. Similarly, Caban-Garcia, Figueroa, and Petruska (2017) also show that the most foreign cross-listing firms are from Canada. The sample is evenly distributed over years.

Table 1. Sample Distribution by Country and Year

Panel A: Country distribution

\begin{tabular}{|c|c|c|c|c|c|}
\hline Country & Frequency & Percent & Country & Frequency & Percent \\
\hline ANT & 2 & 0 & JEY & 3 & 0.01 \\
\hline ARE & 6 & 0.01 & JOR & 1 & 0 \\
\hline ARG & 101 & 0.18 & JPN & 107 & 0.19 \\
\hline AUS & 74 & 0.13 & KOR & 86 & 0.15 \\
\hline BEL & 52 & 0.09 & LUX & 117 & 0.2 \\
\hline BHS & 38 & 0.07 & MAC & 18 & 0.03 \\
\hline BMU & 339 & 0.59 & $\mathrm{MCO}$ & 73 & 0.13 \\
\hline BRA & 226 & 0.39 & MEX & 230 & 0.4 \\
\hline CAN & 2029 & 3.52 & MHL & 13 & 0.02 \\
\hline $\mathrm{CHE}$ & 183 & 0.32 & NLD & 278 & 0.48 \\
\hline CHL & 95 & 0.16 & NOR & 25 & 0.04 \\
\hline $\mathrm{CHN}$ & 1303 & 2.26 & NZL & 5 & 0.01 \\
\hline $\mathrm{COL}$ & 14 & 0.02 & PAN & 18 & 0.03 \\
\hline CYM & 55 & 0.1 & PER & 33 & 0.06 \\
\hline CYP & 5 & 0.01 & PHL & 18 & 0.03 \\
\hline DEU & 69 & 0.12 & PNG & 10 & 0.02 \\
\hline DNK & 31 & 0.05 & RUS & 60 & 0.1 \\
\hline ESP & 37 & 0.06 & SGP & 82 & 0.14 \\
\hline FIN & 19 & 0.03 & SWE & 54 & 0.09 \\
\hline FRA & 125 & 0.22 & THA & 2 & 0 \\
\hline GBR & 806 & 1.4 & TUR & 18 & 0.03 \\
\hline GHA & 3 & 0.01 & TWN & 170 & 0.3 \\
\hline GRC & 139 & 0.24 & URY & 7 & 0.01 \\
\hline HKG & 304 & 0.53 & VEN & 7 & 0.01 \\
\hline IDN & 20 & 0.03 & $\mathrm{ZAF}$ & 112 & 0.19 \\
\hline IND & 120 & 0.21 & Subtotal & 9155 & 15.9 \\
\hline IRL & 444 & 0.77 & USA & 48431 & 84.1 \\
\hline ISR & 900 & 1.56 & & & \\
\hline ITA & 69 & 0.12 & Total & 57586 & 100 \\
\hline
\end{tabular}


Panel B: Year distribution

\begin{tabular}{cccccc}
\hline Year & Frequency & Percent & Year & Frequency & Percent \\
\hline 2000 & 3601 & 6.25 & 2009 & 3029 & 5.26 \\
2001 & 3443 & 5.98 & 2010 & 3042 & 5.28 \\
2002 & 3290 & 5.71 & 2011 & 2981 & 5.18 \\
2003 & 3414 & 5.93 & 2012 & 2980 & 5.17 \\
2004 & 3436 & 5.97 & 2013 & 3076 & 5.34 \\
2005 & 3339 & 5.8 & 2014 & 3150 & 5.47 \\
2006 & 3340 & 5.8 & 2015 & 3099 & 5.38 \\
2007 & 3243 & 5.63 & 2016 & 3085 & 5.36 \\
2008 & 2927 & 5.08 & 2017 & 3111 & 5.4
\end{tabular}

(Table 1 illustrates the sample distribution by country (Panel A) and by year (Panel B) for the full sample, which contains all foreign cross-listing firms and U.S. domestic firms traded on AMEX, NASDAQ, and NYSE from year 2000 to year 2017.)

Table 2 shows the descriptive statistics with the full sample (Panel A) and subsamples of foreign cross-listing firms and U.S. domestic firms (Panel B). The t-statistics indicate that, on average, foreign firms have lower Tobin's q than U.S. firms (1.703 vs. 1.852$)$. In addition, foreign firms generally are larger (7.221 vs. 6.236), more leveraged ( 0.214 vs. 0.209$)$, and have a higher growth trend (0.221 vs. 0.182) than domestic firms. I control for these firm-level differences in the multivariable regression models.

Table 2. Descriptive Statistics

Panel A: Full sample

\begin{tabular}{|c|c|c|c|c|c|c|c|c|}
\hline Variable & $N$ & \multicolumn{2}{|c|}{ Mean } & $25 \%$ & \multicolumn{2}{|c|}{ Median } & $75 \%$ & Std \\
\hline Tobin's $q$ & 57586 & \multicolumn{2}{|c|}{1.828} & 0.890 & \multicolumn{2}{|c|}{1.314} & 2.129 & 1.572 \\
\hline Size & 57586 & \multicolumn{2}{|c|}{6.393} & 4.904 & \multicolumn{2}{|c|}{6.300} & 7.762 & 2.041 \\
\hline$L E V$ & 57586 & \multirow{2}{*}{\multicolumn{2}{|c|}{$\begin{array}{l}0.210 \\
0.188\end{array}$}} & 0.009 & \multicolumn{2}{|c|}{0.168} & 0.333 & 0.210 \\
\hline Grow & 57586 & & & -0.021 & \multicolumn{2}{|c|}{0.080} & 0.228 & 0.572 \\
\hline \multicolumn{9}{|c|}{ Panel B: Subsamples and t-test } \\
\hline & \multicolumn{3}{|c|}{ Foreign cross-listing firms } & \multicolumn{3}{|c|}{ U.S. domestic firms } & \multicolumn{2}{|c|}{ Difference } \\
\hline Variable & $N$ & Mean & Median & $N$ & Mean & Median & \multicolumn{2}{|c|}{$t$-test $(P$-value $)$} \\
\hline Tobin's q & 9155 & 1.703 & 1.554 & 48431 & 1.852 & 1.574 & \multicolumn{2}{|c|}{$<.0001$} \\
\hline Size & 9155 & 7.221 & 2.257 & 48431 & 6.236 & 1.958 & \multicolumn{2}{|c|}{$<.0001$} \\
\hline$L E V$ & 9155 & 0.214 & 0.196 & 48431 & 0.209 & 0.213 & \multicolumn{2}{|c|}{0.0443} \\
\hline Grow & 9155 & 0.221 & 0.610 & 48431 & 0.182 & 0.564 & \multicolumn{2}{|c|}{$<.0001$} \\
\hline
\end{tabular}

(Table 2 shows the descriptive statistics with the full sample (Panel A) and subsamples of foreign cross-listing firms and U.S. domestic firms (Panel B) for firm-level variables, such as firm value, firm size, firm leverage ratio, and firm growth trend.)

Table 3 presents the Person correlation matrix. Firms' market value (Tobin's q ratio) is negatively correlated with the country of a firm's headquarters (the dummy variable Foreign), firm size (Size), and firm leverage (LEV) and is positively related with growth (Grow) at the $1 \%$ level. This univariate test provides preliminary evidence that supports the prediction of Hypotheses 1 and 2. Overall, firm-level characteristics, such as size, leverage, and growth, have an influence on firms' value. The country-level factor of being a foreign firm or not is also associated with firms' value. Given the firm-level differences shown in Table 2, it is necessary to conduct multivariable regression analyses to test whether the findings from Table 3 still hold or not in OLS models. 
Table 3. Pearson Correlation Matrix $(\mathrm{n}=57586)$

\begin{tabular}{|c|c|c|c|c|c|}
\hline & Tobin's q & Foreign & Size & $L E V$ & Grow \\
\hline Tobin's q & 1 & & & & \\
\hline Foreign & $\begin{array}{c}-0.035 \\
(<.0001)\end{array}$ & 1 & & & \\
\hline Size & $\begin{array}{c}-0.210 \\
(<.0001)\end{array}$ & $\begin{array}{c}0.176 \\
(<.0001)\end{array}$ & 1 & & \\
\hline$L E V$ & $\begin{array}{c}-0.146 \\
(<.0001)\end{array}$ & $\begin{array}{c}0.008 \\
(0.0443)\end{array}$ & $\begin{array}{c}0.326 \\
(<.0001)\end{array}$ & 1 & \\
\hline Grow & $\begin{array}{c}0.209 \\
(<.0001)\end{array}$ & $\begin{array}{c}0.025 \\
(<.0001)\end{array}$ & $\begin{array}{c}-0.094 \\
(<.0001)\end{array}$ & $\begin{array}{c}-0.045 \\
(<.0001)\end{array}$ & 1 \\
\hline
\end{tabular}

(Table 3 presents the Person correlation matrix using the full sample. P-value is shown in parentheses.)

\section{Empirical Results}

Table 4 shows the results of Hypothesis 1. The determinants of firm-level characteristics are reported separately for domestic firms (Model 1) and cross-listing foreign firms (Model 2). The coefficients on Size, LEV, and Grow for domestic firms are consistent with prior studies (Daines, 2001; Maury \& Pajuste, 2005; Faleye, 2007; Brick \& Chidambaran, 2010; Ammann et al., 2011). Overall, domestic firms with a larger size, higher leverage level, and slower growing trend are associated with lower market value. For cross-listing foreign firms, the results in Model 2 shows the same sign and similar magnitude for the coefficients on these firm-level characteristics. Therefore, these determinates, which are commonly observed in U.S. domestic firms, also apply to foreign firms. As stated earlier, foreign cross-listing firms share many similarities with their U.S. domestic counterparts. For example, all firms traded in U.S. markets, including both foreign and domestic firms, must comply with the SOX. Furthermore, all firms must file their annual financial reports to the SEC, because, as noted by the SEC commissioner Roel Campos (2003), (Note 4) "After all, US investors are entitled to the same protections regardless of whether an issuer is foreign or domestic."

Table 4. Regression Results for Hypothesis 1

This table tests Hypothesis 1 that U.S. foreign cross-listing firms have the same firm-level value determinants as U.S. domestic firms.

Tobin's $q_{i t}=\alpha_{0}+\alpha_{1}$ Size $_{i t}+\alpha_{2} L E V_{i t}+\alpha_{3}$ Grow $_{i t}+$ Year Dummies $+\varepsilon_{i t}$

\begin{tabular}{ccc}
\hline & $\begin{array}{c}\text { Model 1 (Domestic firms) } \\
\text { Coefficient }\end{array}$ & $\begin{array}{c}\text { Model 2 (Foreign firms) } \\
\text { Coefficient }\end{array}$ \\
\hline Siziable & $-0.134 * * *$ & $-0.118^{* * *}$ \\
LEV & $(-35.912)$ & $(-16.158)$ \\
& $-0.599^{* * *}$ & $-1.041^{* * *}$ \\
Grow & $(-17.747)$ & $(-12.409)$ \\
& $0.546^{* * *}$ & $0.355^{* * *}$ \\
Constant & $(44.786)$ & $(13.799)$ \\
& $2.628^{* * *}$ & $2.800^{* * *}$ \\
Year FE & $(77.327)$ & $(32.527)$ \\
Observations & YES & YES \\
R-squared & 48431 & 9155 \\
\end{tabular}

(Table 4 reports the regression results for Hypothesis 1 that examines firm-level value determinants. Model 1 ( 2 ) 
uses domestic (foreign) firms as the sample. T-statistics are reported in parentheses. ***, **, and * indicate significance at the $1 \%, 5 \%$, and $10 \%$ levels, respectively.)

Test of Hypothesis 2 examines whether country-level characteristics, such as the country of a firm's headquarters, affect its market value. The results are detailed in Table 5. The variable of interest is the dummy variable Foreign. Its coefficient, $\alpha_{1}$, is negatively significant at the $1 \%$ level, indicating that foreign firms are generally undervalued by U.S. investors. More specifically, the Tobin's q ratio of foreign firms is $5.6 \%$ lower than the ratio of domestic firms after controlling for firm size, firm leverage, and firm growth. The results provide supportive evidence for Hypothesis 2 and are in line with the "home bias" phenomenon. There are two possible reasons to explain the discounted market value for foreign cross-listing firms in U.S. markets.

Firstly, prior studies have found that cross-listing firms have a lower reporting quality than U.S. domestic firms. Lang et al. (2016) show that the reconciled earnings from foreign firms have more accruals manipulations to meet or beat earnings targets. This lower earnings quality might be incorporated into firms' value in capital markets. Francis, LaFond, Olsson, and Schipper (2004) show that firms with better earnings quality enjoy a lower cost of capital. Gaio and Raposo (2011) study firms in 38 countries and suggest that firms' market value is positively and significantly related to firms' earnings quality. U.S. investors who hold foreign stocks would either demand a higher return to compensate for the lower earnings quality or reduce the portion of international stocks in their investment portfolios to avoid possible losses, which can lead to the observed "home bias" and discounted firm value.

Secondly, although the SEC monitors all listed firms to "protect investors; maintain fair, orderly, and efficient markets; and facilitate capital formation," (Note 5) there are still several exemptions for foreign cross-listing firms. For example, when filing with the SEC, foreign firms can choose among IFRS, U.S. GAAP, and their home countries' accounting standards (with reconciliation), (Note 6) while U.S. domestic firms must follow U.S. GAAP. Foreign firms are not required to disclose business segment information, which is a mandatory disclosure for domestic firms. Foreign firms have a six-month filing period for their annual reports, but domestic firms have to report their 10-K to the SEC within two months. All of these exemptions and the looser requirements might exacerbate the information asymmetry between foreign firms' insiders and the outside U.S. investors. As a result, U.S. investors are likely to price foreign firms with lower market value.

Table 5. Regression Results for Hypothesis 2

This table tests Hypothesis 2, which claims that foreign cross-listing firms are undervalued relative to U.S. domestic firms in U.S. markets.

\begin{tabular}{|c|c|}
\hline Variable & Coefficient \\
\hline \multirow[t]{2}{*}{ Foreign } & $-0.056^{* * *}$ \\
\hline & $(-3.232)$ \\
\hline \multirow[t]{2}{*}{ Size } & $-0.130 * * *$ \\
\hline & $(-39.156)$ \\
\hline \multirow[t]{2}{*}{$L E V$} & $-0.655^{* * *}$ \\
\hline & $(-20.891)$ \\
\hline \multirow[t]{2}{*}{ Grow } & $0.515 * * *$ \\
\hline & -46.648 \\
\hline \multirow[t]{2}{*}{ Constant } & $2.651 * * *$ \\
\hline & -84.492 \\
\hline Year FE & YES \\
\hline Observations & 57586 \\
\hline$R$-squared & 0.105 \\
\hline
\end{tabular}

(Table 5 reports regression results for Hypothesis 2 that foreign cross-listing firms are undervalued relative to U.S. domestic firms. T-statistics are reported in parentheses. $* * *, * *$, and $*$ indicate significance at the $1 \%, 5 \%$, and $10 \%$ levels, respectively.) 
Hypothesis 3 tests the importance of home countries' legal systems on foreign firms' market value in the U.S. Following prior studies (Dyreng, Hanlon \& Maydew, 2012; Srinivasan et al., 2015; Wilford, 2016), I divide all foreign firms into two subgroups based on the ROL index in their home countries. Table 6 provides results using a dummy variable "Strong" (Model 1) and the actual ROL index as a robustness test (Model 2). Both models show that foreign firms' value is positively associated with the strength of the legal systems in their home countries. More specifically, foreign firms from strong ROL countries overall have a $17.4 \%$ higher Tobin's q ratio than the ratio of foreign firms from weak ROL countries. The finding is consistent with other papers. Eleswarapu and Venkataraman (2006) examine 412 foreign firms listed on the NYSE to test the institutional effects in their home countries on firms' trading costs. They argue that strong legal systems or strong enforcement can decrease cross-listing firms' trading costs by reducing information risk and encouraging investor participation. Lang et al. (2006) also find that the lower earnings quality among foreign cross-listing firms is more severe when they are from countries with weak legal environments. Wilford (2016) tests another perspective of firms' reporting quality - internal material weaknesses and concludes that "foreign firms that are classified as strong rule of law countries are less likely to report material weaknesses and foreign firms that are classified as weak rule of law countries are more likely to report material weaknesses" (page 276). Overall, foreign firms from strong ROL countries, compared with foreign firms from weak ROL countries, are more likely to have better earnings quality and less information risk, which leads to higher market value.

Table 6. Regression Results for Hypothesis 3

This table tests Hypothesis 3, which claims that foreign cross-listing firms' value in U.S. markets is associated with their home countries' legal systems.

\begin{tabular}{|c|c|c|c|}
\hline \multirow[b]{2}{*}{ Variable } & \multirow{2}{*}{$\begin{array}{c}\text { Model } 1 \text { (Dummy variable Strong) } \\
\text { Coefficient }\end{array}$} & \multicolumn{2}{|c|}{ Model 2 (Actual ROL index value) } \\
\hline & & Variable & Coefficient \\
\hline \multirow[t]{2}{*}{ Strong } & $0.174 * * *$ & ROL-Index & $0.167 * * *$ \\
\hline & $(4.906)$ & & $(9.244)$ \\
\hline \multirow[t]{2}{*}{ Size } & $-0.122 * * *$ & Size & $-0.127 * * *$ \\
\hline & $(-16.205)$ & & $(-16.933)$ \\
\hline \multirow[t]{2}{*}{$L E V$} & $-1.096 * * *$ & $L E V$ & $-1.104 * * *$ \\
\hline & $(-12.438)$ & & $(-12.583)$ \\
\hline \multirow[t]{2}{*}{ Grow } & $0.302 * * *$ & Grow & $0.303 * * *$ \\
\hline & $(12.832)$ & & (12.904) \\
\hline \multirow[t]{2}{*}{ Constant } & $2.736 * * *$ & Constant & $2.714 * * *$ \\
\hline & $(29.618)$ & & $(30.223)$ \\
\hline Year FE & YES & Year FE & YES \\
\hline Observations & 9155 & Observations & 9155 \\
\hline$R$-squared & 0.107 & $R$-squared & 0.113 \\
\hline
\end{tabular}

(Table 6 reports results for Hypothesis 3 that foreign cross-listing firms' value in U.S. markets is associated with their home countries' legal systems. Model 1 (2) uses the dummy variable Strong (the actual ROL index value). $\mathrm{T}$-statistics are reported in parentheses. $* * *, * *$, and $*$ indicate significance at the $1 \%, 5 \%$, and $10 \%$ levels, respectively.)

I also perform additional tests to explore whether the undervaluation observed in Table 5 is homogeneous across all foreign firms. To do this, I first compare firms' value between foreign firms with strong ROL and U.S. domestic firms. Then I perform the same test using foreign firms with weak ROL and U.S. domestic firms. Results are presented in Table 7. The insignificant coefficient on the variable Foreign in Model 1 indicates that there is no observable difference between strong ROL foreign firms and domestic firms in terms of firm value. In contrast, the coefficient on the variable Foreign in Model 2 is negatively significant, suggesting that, on average, the Tobin's q ratio for foreign firms from weak ROL countries is $21.7 \%$ lower than the ratio of domestic firms. The difference is not only statistically significant at the $1 \%$ level, but also economically significant. The finding is consistent with 
Srinivasan et al. (2015), who find that firms' internal control weakness can only predict the restatement frequency for U.S. domestic firms and foreign firms from strong ROL countries, but not for foreign firms from weak ROL countries. Taken together, the observed undervaluation between foreign firms and domestic firms in Table 5 can be mainly attributed to foreign firms from weak ROL countries. Therefore, a strong legal system in foreign firms' home countries can effectively mitigate the discounted firm value in U.S. markets.

Table 7. Additional Tests

This table provides the results for additional tests. Model 1 (2) shows the results of firm value comparison between foreign firms from strong (weak) ROL countries and U.S. domestic firms.

\begin{tabular}{cccc}
\hline & $\begin{array}{c}\text { Model 1 ( } \\
\text { firms vs. domestic firms) } \\
\text { Coefficient }\end{array}$ & Variable & $\begin{array}{c}\text { Model 2 (Weak ROL foreign } \\
\text { firms vs. domestic firms) } \\
\text { Coefficient }\end{array}$ \\
\hline Foreign & 0.008 & Foreign & $-0.217^{* * *}$ \\
Size & $(0.408)$ & & $(-7.238)$ \\
& $-0.133^{* * *}$ & Size & $-0.132^{* * *}$ \\
LEV & $(-39.301)$ & & $(-36.176)$ \\
& $-0.624 * * *$ & LEV & $-0.616^{* * *}$ \\
Grow & $(-19.665)$ & & $(-18.664)$ \\
& $0.498^{* * *}$ & Grow & $0.578^{* * *}$ \\
Constant & $(44.832)$ & & $(47.162)$ \\
& $2.663^{* * *}$ & Constant & $2.612^{* * * *}$ \\
Year FE & $(84.071)$ & & $(77.895)$ \\
Observations & YES & Year FE & YES \\
R-squared & 54925 & Observations & 51092 \\
\hline
\end{tabular}

(Table 7 reports the results for additional tests. Model 1 (2) shows the results of firm value comparison between foreign firms from strong (weak) ROL countries and U.S. domestic firms. T-statistics are reported in parentheses. $* * *, * *$, and $*$ indicate significance at the $1 \%, 5 \%$, and $10 \%$ levels, respectively.)

The country distribution in Table 1 shows that Canadian firms count for $3.52 \%$ of the full sample. Therefore, it is necessary to repeat all tests after excluding the Canadian observations. Results are presented in Table 8. All results hold with the various sample observations, suggesting that the findings are not driven by any specific country or firms. 
Table 8. Robustness Test after Excluding Canadian Observations

This table provides the results of the robustness test after excluding Canadian observations from the sample. Model 1 repeats the firm-level value determinants of Table 4. Model 2 repeats the firm value between foreign firms and domestic firms of Table 5. Models 3 and 4 repeat the dummy variable "Strong" and the actual ROL index value from Table 6. Model 5 repeats Table 7, with comparison between strong ROL foreign firms and domestic firms. Since all Canadian firms are classified as strong ROL firms, the test in Table 7's Model 2 of comparing weak ROL foreign firms and domestic firms is not affected or repeated.

\begin{tabular}{|c|c|c|c|c|c|}
\hline Variables & $\begin{array}{c}\text { Modell } \\
\text { Coefficient }\end{array}$ & $\begin{array}{c}\text { Model2 } \\
\text { Coefficient }\end{array}$ & $\begin{array}{c}\text { Model3 } \\
\text { Coefficient }\end{array}$ & $\begin{array}{c}\text { Model4 } \\
\text { Coefficient }\end{array}$ & $\begin{array}{c}\text { Model5 } \\
\text { Coefficient }\end{array}$ \\
\hline \multirow[t]{2}{*}{ Foreign } & & $-0.079 * * *$ & & & 0.004 \\
\hline & & $(-4.107)$ & & & -0.152 \\
\hline \multirow[t]{2}{*}{ Strong } & & & $0.165 * * *$ & & \\
\hline & & & -4.39 & & \\
\hline \multirow[t]{2}{*}{ ROL-Index } & & & & $0.183^{* * *}$ & \\
\hline & & & & -9.037 & \\
\hline \multirow[t]{2}{*}{ Size } & $-0.080 * * *$ & $-0.123^{* * *}$ & $-0.083^{* * *}$ & $-0.092 * * *$ & $-0.126 * * *$ \\
\hline & $(-9.677)$ & $(-36.531)$ & $(-10.027)$ & $(-11.069)$ & $(-36.685)$ \\
\hline \multirow[t]{2}{*}{$L E V$} & $-1.152 * * *$ & $-0.654 * * *$ & $-1.145^{* * *}$ & $-1.167 * * *$ & $-0.620 * * *$ \\
\hline & $(-11.965)$ & $(-20.634)$ & $(-11.900)$ & $(-12.185)$ & $(-19.360)$ \\
\hline \multirow[t]{2}{*}{ Grow } & $0.348 * * *$ & $0.531 * * *$ & $0.354 * * *$ & $0.360 * * *$ & $0.529 * * *$ \\
\hline & -11.982 & -46.655 & -12.196 & -12.461 & -45.245 \\
\hline \multirow[t]{2}{*}{ Constant } & $2.558 * * *$ & $2.603 * * *$ & $2.455^{* * *}$ & $2.458 * * *$ & $2.608 * * *$ \\
\hline & -24.942 & -81.545 & -23.361 & -23.962 & -81.015 \\
\hline Year FE & YES & YES & YES & YES & YES \\
\hline Observations & 7126 & 55557 & 7126 & 7126 & 52896 \\
\hline$R$-squared & 0.092 & 0.104 & 0.095 & 0.103 & 0.104 \\
\hline
\end{tabular}

(Table 8 reports the results of the robustness test after excluding Canadian observations from the sample. T-statistics are reported in parentheses. $* * *, * *$, and $*$ indicate significance at the $1 \%, 5 \%$, and $10 \%$ levels, respectively.)

\section{Conclusion}

The purpose of this study is to examine how foreign firms are valued after cross-listing shares in the U.S. markets. Prior studies have generally agreed with the cross-listing premium relative to non-cross-listers in their home countries. However, less research has been conducted to examine whether these foreign firms are valued similarly or differently from U.S. domestic firms after the cross-listing takes place.

Using both foreign firms and domestic firms listed on the three major U.S. stock exchanges (AMEX, NASDAQ, and NYSE) between 2000 and 2017, this study examines the firm value using both firm-level characteristics and country-level characteristics. Results reveal that, although foreign firms share similar firm-level determinants with U.S. firms (firm size, firm leverage, and firm growth), they are on average undervalued by U.S. investors. Multivariable regression tests show that the Tobin's q ratio of foreign firms is 5.6\% lower than that of U.S. domestic firms. Within foreign firms, their firm value is positively associated with the strength of the legal systems in their home countries. In fact, the undervaluation between foreign firms and U.S. domestic firms disappears when foreign firms come from countries with strong ROL. In contrast, foreign firms from weak ROL countries have a Tobin's q ratio that is $21.7 \%$ lower than the ratio of domestic firms. This difference is not only statistically significant at the $1 \%$ level, but also economically significant. In conclusion, not only the firm-level characteristics but also the home country characteristics are considered by U.S. investors when they value foreign firms after cross-listing in the U.S.

My study extends prior literature by directly examining foreign firms' market value after the cross-listing at both the firm and country levels. For U.S. cross-listing studies, Eleswarapu and Venkataraman (2006) analyze how home 
countries' institutions influence cross-listing firms' trading costs. Lee and Valero (2010) investigate the effect of cross-listing on foreign firms' information environment. They argue that the effect depends on firms' listing types and home countries' characteristics. Srinivasan et al. (2015) find that foreign firms are less likely to admit their financial mistakes and restate the annual reports relative to U.S. firms. Wilford (2016) examines firms' internal control weaknesses by comparing cross-listing firms and domestic firms. He finds that foreign firms overall have more material weaknesses than U.S. firms and that material weaknesses vary with home countries' ROL. However, none of these studies looks at how U.S. investors perceive the similarities and differences between cross-listing firms and domestic firms and how investors price and value the two types of firms in U.S. markets. Results from my study suggest that at the firm level, foreign firms and domestic firms share the same value determinants, while at the country level, foreign firms overall are undervalued by market participants. These findings should be of interest to investors, analysts, and policy setters.

One limitation of the current study is that it only uses the ROL as the proxy for home countries' characteristics. Prior studies have employed various proxies for home countries' characteristics. For example, Caban-Garcia, Figueroa, and Petruska (2017) notice that the culture in foreign firms' home countries can affect these firms' internal control weaknesses. Beckmann, Escobari, and Ngo (2019) find that cross-listing firms' earnings management is associated with the development level in their home countries. Future studies can separate the foreign cross-listing firms based on other proxies and provide new evidences on determinants of foreign firms' value in U.S. markets.

\section{References}

Ammann, M., Oesch, D. \& Schmid, M. M. (2011). Corporate governance and firm value: International evidence. Journal of Empirical Finance, 18(1), 36-55. https://doi.org/10.1016/j.jempfin.2010.10.003

Beckmann, K. S., Escobari, D. A. \& Ngo, T. (2019). The real earnings management of cross-listing firms. Global Finance Journal, 41, 128-145. https://doi.org/10.1016/j.gfj.2019.04.001

Bell, R. G., Filatotchev, I. \& Rasheed, A. A. (2012). The liability of foreignness in capital markets: Sources and remedies. Journal of International Business Studies, 43(2), 107-122. https://doi.org/10.1057/jibs.2011.55

Bonetti, P. \& Bozzolan, S. (2015). Cross-listing and firm information environment: Does SOX section 302 have any material effect?. Working paper.

Brick, I. E. \& Chidambaran, N. K. (2010). Board meetings, committee structure, and firm value. Journal of Corporate Finance, 16(4), 533-553. https://doi.org/10.1016/j.jcorpfin.2010.06.003

Caban-Garcia, M. T., Figueroa, C. B. R. \& Petruska, K. A. (2017). The impact of culture on internal control weaknesses: Evidence from firms that cross-list in the US. Journal of International Accounting Research, 16(3), 119-145. https://doi.org/10.2308/jiar-51916

Callahan, W. T., Millar, J. A. \& Schulman, C. (2003). An analysis of the effect of management participation in director selection on the long-term performance of the firm. Journal of Corporate Finance, 9(2), 169-181. https://doi.org/10.1016/S0929-1199(02)00004-4

Chung, K. H. \& Pruitt, S. W. (1994). A simple approximation of Tobin's q. Financial Management, 70-74. https://doi.org/10.2307/3665623

Coffee Jr, J. C. (2002). Racing towards the top: The impact of cross-listing and stock market competition on international corporate governance. Columbia Law Review, 102(7), 1757-1831. https://doi.org/10.2307/1123661

Daines, R. (2001). Does Delaware law improve firm value?. Journal of Financial Economics, 62(3), 525-558. https://doi.org/10.1016/S0304-405X(01)00086-1

Doidge, C., Karolyi, G. A. \& Stulz, R. M. (2004). Why are foreign firms listed in the US worth more?. Journal of Financial Economics, 71(2), 205-238. https://doi.org/10.1016/S0304-405X(03)00183-1

Dyreng, S. D., Hanlon, M. \& Maydew, E. L. (2012). Where do firms manage earnings?. Review of Accounting Studies, 17(3), 649-687. https://doi.org/10.1007/s11142-012-9194-7

Eleswarapu, V. R. \& Venkataraman, K. (2006). The impact of legal and political institutions on equity trading costs: A cross-country analysis. The Review of Financial Studies, 19(3), 1081-1111. https://doi.org/10.1093/rfs/hhj026

El-Gazzar, S. M. \& Finn, P. M. (2017). Restatements and accounting quality: a comparison between IFRS and US-GAAP. Journal of Financial Reporting and Accounting, 15(1), 39-58. https://doi.org/10.1108/JFRA-10-2015-0090 
Faleye, O. (2007). Classified boards, firm value, and managerial entrenchment. Journal of Financial Economics, 83(2), 501-529. https://doi.org/10.1016/j.jfineco.2006.01.005

Ferris, S. \& Liao, M. (2018). Relative governance and the global cross-listing decision: extending the bonding hypothesis. Accounting and Finance Research, 7(1), 82-98. https://doi.org/10.5430/afr.v7n1p82

Foerster, S. R. \& Karolyi, G. A. (1998). Multimarket trading and liquidity: a transaction data analysis of Canada-US interlistings. Journal of International Financial Markets, Institutions and Money, 8(3-4), 393-412. https://doi.org/10.1016/S1042-4431(98)00049-3

Francis, J., LaFond, R., Olsson, P. M. \& Schipper, K. (2004). Costs of equity and earnings attributes. The accounting review, 79(4), 967-1010. https://doi.org/10.2308/accr.2004.79.4.967

French, K. R. \& Poterba, J. M. (1991). Investor diversification and international equity markets (No. w3609). National Bureau of Economic Research. https://doi.org/10.3386/w3609

Frésard, L. \& Salva, C. (2010). The value of excess cash and corporate governance: Evidence from US cross-listings. Journal of Financial Economics, 98(2), 359-384. https://doi.org/10.1016/j.jfineco.2010.04.004

Gaio, C. \& Raposo, C. (2011). Earnings quality and firm valuation: international evidence. Accounting \& Finance, 51(2), 467-499. https://doi.org/10.1111/j.1467-629X.2010.00362.x

Hail, L. \& Leuz, C. (2009). Cost of capital effects and changes in growth expectations around US cross-listings. Journal of Financial Economics, 93(3), 428-454. https://doi.org/10.1016/j.jfineco.2008.09.006

Karolyi, G. A. (1998). Why do companies list shares abroad?: A survey of the evidence and its managerial implications. Financial Markets, Institutions \& Instruments, 7(1), 1-60.https://doi.org/10.1111/1468-0416.00018

Karolyi, G. A. \& Stulz, R. M. (2003). Are financial assets priced locally or globally?. Handbook of the Economics of Finance, 1, 975-1020. https://doi.org/10.1016/S1574-0102(03)01025-2

Kaya, D. \& Pillhofer, J. A. (2013). Potential adoption of IFRS by the United States: a critical view. Accounting Horizons, 27(2), 271-299. https://doi.org/10.2308/acch-50423

Lang, M., Raedy, J. S. \& Wilson, W. (2006). Earnings management and cross listing: Are reconciled earnings comparable to US earnings?. Journal of Accounting and Economics, 42(1-2), 255-283. https://doi.org/10.1016/j.jacceco.2006.04.005

Lee, H. W. \& Valero, M. (2010). Cross-listing effect on information environment of foreign firms: ADR type and country characteristics. Journal of Multinational Financial Management, 20(4-5), 178-196. https://doi.org/10.1016/j.mulfin.2010.07.006

Leuz, C. (2003). Discussion of ADRs, analysts, and accuracy: Does cross-listing in the United States improve a firm's information environment and increase market value?. Journal of Accounting Research, 41(2), 347-362. https://doi.org/10.1111/1475-679X.00107

Lewis, K. K. (1999). Trying to explain home bias in equities and consumption. Journal of Economic Literature, 37(2), 571-608. https://doi.org/10.1257/jel.37.2.571

Lindenberg, E. B. \& Ross, S. A. (1981). Tobin's q ratio and industrial organization. Journal of Business, 1-32. https://doi.org/10.1086/296120

Maury, B. \& Pajuste, A. (2005). Multiple large shareholders and firm value. Journal of Banking \& Finance, 29(7), 1813-1834. https://doi.org/10.1016/j.jbankfin.2004.07.002

Mittoo, U. R. (1992). Managerial perceptions of the net benefits of foreign listing: Canadian evidence. Journal of International Financial Management \& Accounting, 4(1), 40-62. https://doi.org/10.1111/j.1467-646X.1992.tb00021.x

Oxelheim, L. \& Randøy, T. (2003). The impact of foreign board membership on firm value. Journal of Banking \& Finance, 27(12), 2369-2392. https://doi.org/10.1016/S0378-4266(02)00395-3

Smith, D. D., Gleason, K. C., Wiggenhorn, J. \& Kannan, Y. H. (2018). Auditors' assessment of the capital market liability of foreignness. Review of Accounting and Finance, 17(1), 109-129. https://doi.org/10.1108/RAF-06-2016-0090

Smith, K. \& Sofianos, G. (1997). The impact of an NYSE listing on the global trading of non-US stocks. New York Stock Exchange. 
Srinivasan, S., Wahid, A. S. \& Yu, G. (2015). Admitting mistakes: Home country effect on the reliability of restatement reporting. The Accounting Review, 90(3), 1201-1240. https://doi.org/10.2308/accr-50887

Strong, N. \& Xu, X. (2003). Understanding the equity home bias: Evidence from survey data. Review of Economics and Statistics, 85(2), 307-312. https://doi.org/10.1162/003465303765299837

Sun, J., Cahan, S. F. \& Emanuel, D. (2011). How would the mandatory adoption of IFRS affect the earnings quality of US firms? Evidence from cross-listed firms in the US. Accounting Horizons, 25(4), 837-860. https://doi.org/10.2308/acch-50049

Wilford, A. L. (2016). Internal control reporting and accounting standards: A cross-country comparison. Journal of Accounting and Public Policy, 35(3), 276-302. https://doi.org/10.1016/j.jaccpubpol.2015.12.006

\section{Notes}

Note 1. The number of foreign cross-listing firms is calculated using the Compustat database

Note 2. Based on the definition from the World Bank (https://databank.worldbank.org/databases/rule-of-law), the ROL captures "perceptions of the extent to which agents have confidence in and abide by the rules of society, particularly the quality of contract enforcement, property rights, the police, and the courts as well as the likelihood of crime and violence."

Note 3. https://databank.worldbank.org/databases/rule-of-law

Note 4. https://www.sec.gov/news/speech/spch061103rcc.htm

Note 5. https://www.investor.gov/introduction-investing/basics/role-sec

Note 6. https://www.sec.gov/corpfin/cf-manual/topic-6 